\title{
Investigation and Analysis on the Interactive Effectiveness of Foreign Language Teaching under the Network Environment
}

\author{
Zhaoxi Wei \\ Beijing Information Technology College \\ Beijing, China 100018
}

\begin{abstract}
It has been the best choice to improve the effects of foreign language teaching and stimulate students' independent learning ability through modern educational technology and network resources. In order to understand the implementation and feedback of foreign language under the informatization support, the research group distributes the questionnaires on the self-knowledge on the current situation of foreign language learning, the class application of foreign language teaching and the evaluation on foreign language aptitude. According to the statistics and analysis on the questionnaire data, foreign language learners have clear cognition and make plans in learning in the network environment, but they lack the initiative and need the effective guidance of teachers; the implementation effect of foreign language teaching is satisfactory. The harmonious and relaxed classroom atmosphere under the informatization support can reduce students' anxiety in learning foreign languages and help the effective implementation of teaching activities. Foreign language teaching under the network environment requires teachers to update the teaching contents and pay close attention to learners' demands for individualized learning, specific guidance and the establishment of learning community. Therefore, it is imperative to attach importance to the practical application ability of foreign language, further optimize the organization pattern of classroom teaching and innovate in the diversified evaluation pattern in the information era.
\end{abstract}

Keywords-network environment; foreign language teaching; interactive effectiveness; investigation

\section{INTRODUCTION}

In recent years, with the changes and adjustment of national educational ideas and policies, it is imperative to reform the foreign language teaching. According to the statement of professional technical education and professional curriculum reform in the Outline of the National Medium and Long Term Education Reform and Development Plan, it pays more attention to the connection between teachers' instruction and students' subjective initiative and the cultivation of students' independent learning ability as well as the idea of lifelong learning. Therefore, it is necessary to enrich the teaching methods of foreign language courses through modern educational technology and network resources, maximize the

Fund support: 2015 Beijing college educational reform project; project name: Research on the Investigation and Optimization of Interactive Effectiveness of Foreign Language Teaching under the Network Environment project number 2015-ms217. learning effects in classroom teaching and stimulate students' independent learning ability, improving students' ability in language practice. In order to better serve the teaching reform of foreign language and understand the implementation and feedback of foreign language teaching under the network environment, the research group designs from the selfknowledge of foreign language learners, the implementation of foreign language teaching and the evaluation on foreign language learning under the informatization support. The results will show on the questionnaire star. College students investigated in Beijing and using the Moso Teach to aid the foreign language teaching fill in it on mobile phones. There are 819 valid questionnaires collected in this investigation.

\section{THE RESULT OF INVESTIGATION ON FOREIGN} LANGUAGE LEARNERS' SELF-KNOWLEDGE AND SELF-PLAN UNDER THE NETWORK ENVIRONMENT

Students clearly understand the current situation and make plans in the foreign language learning, but they lack the subjective initiative and needs the effective guidance of teachers. Specifically speaking:

- In the self-knowledge and evaluation of foreign language learning, in answering the question "Are you satisfied with your situation in foreign language learning before admission?", the proportions of students satisfied and dissatisfied are near, namely $50.06 \%$ and $49.94 \%$ respectively. Meanwhile, $39.68 \%$ of students think the key to learn foreign languages is "me" and $32.6 \%$ choose the interest. Obviously, students can clearly understand the current situation of foreign language learning, which will influence whether they can design personalized plans or learning objectives. According to the data, nearly $30 \%$ of students can take the initiative to plan or set goals in foreign language learning; $36 \%$ of students (clearly) and $24 \%$ (not very clearly) plan the foreign language teaching under the effective guidance of teachers step by step, and then develop personalized learning habits in taking the initiative to plan or set goals. At present, students' behaviors in learning foreign language consciously are mainly under the influence of emotional factors, like anxiety, self-abasement or repression and shyness. Moreover, $31 \%$ of students 
"never" or "seldom" take actions actively to overcome the negative emotional factors; $31 \%$ "never" or "seldom" take the initiative to cooperate with others in learning. Students sometimes "actively overcome negative emotional factors" or "take the initiative to cooperate with others in learning" account for $44.08 \%$ and $42.49 \%$ respectively. In order to let students become initiative in learning, the key is to eliminate the factors causing students' anxiety in foreign language learning, strengthening their willingness of initiative learning. It necessary to give enough confidence and teach strategies and means to students in active learning, in order to let the active foreign language communication become a meaningful part of foreign language learning.

- Besides, for students as "Digital Natives" born after 1995, the mobile phone network has been indispensable in their learning and life. With the mobile micro learning brought by the mobile phones, it is hopeful to reduce the proportion of people "never" "take the initiative to learn foreign languages through the network" from $15.38 \%$ to zero. Therefore, it is imperative to discuss the teaching contents, design the teaching task and research the project of mobile micro learning under the information-based teaching environment, which furthest highlight and exert the function of informatization in supporting the foreign language teaching.

\section{INVESTIGATION ON THE IMPLEMENTATION STATUS AND EFFECT OF INTERACTION IN FOREIGN LANGUAGE CLASS UNDER THE NETWORK ENVIRONMENT}

We can know the degree of satisfaction for the current situation of foreign language teaching through eight aspects, including: (1). The content feedback of foreign language interactive teaching; (2). The interactive teaching method; (3). The design of interactive teaching process; (4). The appeal of classroom teaching; (5). The creation of classroom atmosphere; (6). The feedback of interactive classroom teaching mode; (7). The requirements of classroom teaching evaluation; (8). The effect of informational supplementary means, showing as follows:

- The overall degree of satisfaction for the interactive teaching of foreign language is $92 \%$, similar to that of other aspects, showing the effectiveness of the survey result. Foreign language learners are very satisfied with the methods and process design of foreign language interactive teaching and the application of informational teaching means. It shows: the promotion of network course platform, Moso Teach and Longman online platform in universities has obvious effects on the foreign language interactive teaching; in order to apply the informational teaching means, it is necessary to understand the textbook thoroughly, reflect the teaching methods and elaborately design the teaching process and means. Teachers should adhere to the principle of "make hard things simple", "turn the difficult into the easy" and "progressive layers", arouse students' interests in the leading-in, and emphasize the key and difficult points, combining the teaching with the practice, highlighting the practical function of language and students' dominant role and embodying the "student-centered" concept. Students that think the class is popular and improves the participation rate account for $80 \%$; $89 \%$ of students think the harmonious classroom climate is "relaxed and pleasant" and "quiet and comfortable". It helps to reduce students' anxiety in learning foreign languages and let students have a feeling of dependency on teachers. In this way, it helps the organization of activities in foreign language class, the implementation of interactive teaching strategies and the instruction of teaching contents as well as the improvement of teaching effects.

- According to the investigation on the interactive activities in the foreign language class, group activities and topic discussion that can improve the ability in oral expression, cooperation ability and critical thinking skills are popular among students and can arouse their interests; moreover, independent learning activities also rank the top three of favorite activities. It shows under the web-based teaching environment, students have more requirements for information and personal learning space than the traditional teaching environment of "blackboard and chalk". On one hand, it requires teachers to pay more attention to the proper application of web-based teaching means and continuously update the information, topic, content and method, which embody in the evaluation of classroom teaching mode. The classroom content, method and activity that cannot stimulate students' initiative account for $50 \%, 37.61 \%$ and $25.4 \%$ respectively. On the other hand, teachers should adhere to the principle of "less is more". Students should have "leeway" to think more and the time or space to learn independently, which helps them to understand the teaching contents and trains their ability in reflection and in-depth learning.

- The involvement of informational teaching means greatly affects foreign language learners, stimulates their learning interests $(33.7 \%)$, presents the diversified learning resources $(45.42 \%)$ and provides students with another form to participate in activities $(46.89 \%)$. It has built the three-dimensional teaching space and let students free from the embarrassment and fear in class. Students participate in the classroom learning of foreign language. It is a positive feedback of training students' ability in independent and selfconscious learning. In the interactive teaching of foreign language under the informational teaching means, students yearn for the answering of questions at any time $(49.82 \%)$ and the repeated reflection of knowledge points $(49.82 \%)$, the one-to-one assisted learning $(33.58 \%)$ and the establishment of learning community $(33.58 \%)$. It fully embodies the individualized and targeted foreign language interactive learning under the informational teaching 
environment and the teamwork of learning community. Therefore, it requires the update of teaching contents, the improvement of learning styles under the support of information technology and the deep understanding of foreign language learners' demands.

- Currently, the proportions of students who think they do not need and be indifferent to interactive activities like comments or feedback between teachers and students account for $10.26 \%$ and $21.61 \%$ respectively. On one hand, most students still need teachers' comments and feedback to lay foundation or improve the next step of learning; on the other hand, students cannot feel the necessity or guidance value of the comments on their learning because the forms of teachers' comments or feedback are single and blind. Therefore, it will bring different effects of interactive classroom teaching if the comments or feedbacks are timely, targeted and diversified.

\section{STUDENTS' SUGGESTIONS FOR THE IMPROVEMENT OF FOREIGN LANGUAGE INTERACTIVE TEACHING UNDER THE NETWORK ENVIRONMENT}

We have investigated the establishment of foreign language teachers' role under the environment of information technology, the application of interactive teaching methods under the support of informatization, the dynamic integration of informatization and teaching contents as well as the training of foreign language ability under the network environment. It shows as follows:

- The foreign language teachers' role gradually changes under the environment of information technology. The knowledge transmitter accounts for $68.38 \%$. It shows teachers are the embodiment of wisdom and the main transmitter of knowledge as well as authoritative in the eyes of the students. In the era of knowledge explosion and the flooding of fragmented knowledge, although it is demanding and impossible for teachers to know everything, it has higher demands for teachers. Therefore, teachers should play the correct leading role, keep pace with the times and innovate continuously. Secondly, students expect foreign language teachers can become instructors (58.24\%) and analyzers $(46.51 \%)$ of the learning activities. Moreover, foreign language teachers should become the designers of classroom activities to yield twice the result with half the effort in teaching effects; it can furthest exert students learning initiative and realize the independent study via understanding students, training the sensitivity for students' needs and helping them to formulate learning plans and objectives in accordance with their requirements.

- The interactive teaching methods under the informatization support are to activate the classroom and improve students' participation. The independent learning activities and practices $(51.16 \%)$ on APP are more popular among students. After all, the mobile phones and network have become indispensable tools in students' life. Therefore, it is easy to stimulate students' enthusiasm through creating or sharing learning activities and practices on APP. Activities like topic discussion $(47.74 \%)$ and group activities (45.79\%) help to improve the ability in oral expression, cooperative ability and critical thinking skills. Teachers can organize these activities according to the teaching objectives and requirements in order to arouse students' enthusiasm, activate the classroom and improve the teaching effects.

- Under the dynamic integration of informatization and teaching contents, students hope to improve the basic skills of foreign language like listening and speaking $(65.45 \%)$, learn contents related to the employment in the future $(56.29 \%)$ and contents related to personal cultivation and social etiquettes (42.61\%). Furthermore, students pay more attention to the improvement and training of their foreign language communication skills $(80.22 \%)$, the acquisition of language knowledge for the appropriate expression on the job market $(56.9 \%)$ and the identification of cooperation and communication skills in the job market $(48.96 \%)$. In the integration of informatization and teaching contents, we should pay attention to the training of career ability and language skills like listening, speaking, reading and writing and provide the language knowledge.

- Train abilities. According to the investigation on foreign language learning objectives under the network environment, $76.8 \%$ of foreign language learners require the graduation certificate, $60.56 \%$ pursue the job opportunities and $50.43 \%$ pursue the further education; $59.1 \%$ want to improve the foreign language expression ability and $47.5 \%$ pursue the communicative ability in job market. Therefore, teachers should widely use the internet, build the "foreign language certificate consulting library" or "career foreign language information base" to make full preparation for students to get job qualification certificates and train their vocational ability. Meanwhile, teachers should carry out online questionnaire or investigation to know about the current situation and requirements of students in foreign language learning and the on-to-one or targeted teaching guidance. Therefore, teachers should attentively treat and understand students and plan classroom activities.

\section{CONCLUSION}

The investigation shows in universities carrying out or using informational teaching means to assist foreign language teaching under the network environment, students are satisfied with the current situation of foreign language teaching. The reasons are as follows: On one hand, students preview the foreign language courses before using the informational technical means, and teachers plan the interactive activities or forms ahead of time and the after-class online small tests, and forecast problems or effects. On the other hand, under the historical background of "Internet Plus", the application and promotion of informational teaching means in classroom 
teaching activate the class and improve the degree of participation. The teaching status improves through the organic integration of information technology, interactive teaching model and foreign language teaching. Meanwhile, the interactive teaching of foreign language under the network environment should:

- The means and forms of informatization update or enrich in the foreign language teaching. It still needs to strengthen the practical application ability of foreign language, attach importance to listening and speaking to strengthen the communicative competence of foreign language, which are the strong request of students and the objective of foreign language teaching under the current network environment.

- It has become the basic consensus in the organization of foreign language teaching under the informatization support to organize the "student-centered" classroom teaching, enlighten, guide and train students' independent learning ability. In the traditional teaching model, foreign language learners lack the ability to learn foreign language independently and spend insufficient time in it. The teaching organization forms must train the ability in applying foreign language. Therefore, it should be the main method and means of foreign language teaching to carry out the interactive teaching between teachers and students based on teachers' heuristic teaching and the informational teaching means.

- It is necessary to apply the diversified evaluation model and innovate in the standard, content, method and principle part of evaluation. The evaluation model must show students with different foreign language abilities gain the recognition through efforts; the assessment standard of different levels can furthest embody the application ability of foreign language that students have formed instead of encouraging high scores and low abilities; students should be helped to get foreign language qualification certificate acknowledged by the society.

\section{REFERENCES}

[1] Wu Yonghe. The Meaningful Interaction in the Web-based Learning: The Perspective of Social Constructivism [J], Distance Education in China, 2014(01)

[2] Hu Jiehui, Wu Zhongiie. Research on the Teaching Model of College English Flipped Class Based on MOOC [J], Computer-assisted Foreign Language Education, 2014(11)

[3] Zhaoxi Wei, Gang Ji. Discussion on Effective Optimization of Foreign Language Teaching Interaction under Network Environment [J]. ICADCE 2016, Atlantis Press, 2016(05)

[4] Wei Zhaoxi. Exploration on Transforming the Network Resources into the Teaching Resources of Foreign Language Course under the Informatization Teaching Environment $[\mathrm{J}]$, Science and Technology Version, 2016(18). 